\title{
Environmental justice and the SDGs: from synergies to gaps and contradictions
}

\author{
Mary Menton $^{1}(1) \cdot$ Carlos Larrea $^{2} \cdot$ Sara Latorre $^{3} \cdot$ Joan Martinez-Alier ${ }^{4} \cdot$ Mika Peck $^{1} \cdot$ Leah Temper $^{5} \cdot$ Mariana Walter $^{4}$
}

Received: 14 January 2019 / Accepted: 19 February 2020 / Published online: 9 April 2020

(c) The Author(s) 2020

\begin{abstract}
Through their synergies, trade-offs, and contradictions, the sustainable development goals (SDGs) have the potential to lead to environmental justices and injustices. Yet, environmental justice (EJ), and social justice more broadly, are not currently embedded within the language and spirit of the SDGs. We part from the premise that "many 'environmental' problems are, by their very nature, problems of justice" (Lele, Wiley Interdiscip Rev Water 4:e1224, 2017). We review progress in EJ frameworks in recent years, arguing for the need to move beyond a focus on the four principles of mainstream EJ (distribution, procedure, recognition, and capabilities) towards a more intersectional decolonial approach to environmental justice that recognises the indispensability of both humans and non-humans. EJ frameworks, and the SDGs should recognise power dynamics, complex interactions among injustices, and listens to the different 'senses of justice' and desires of theorists, activists, and other stakeholder from the Global South. We analyze how EJ frameworks are, or fail to be, incorporated in the SDGs with a focus on the food-water-health nexus (SDG2, 3, 6); climate-energy (SDG7, 13), conservation (SDG14, $15)$; and poverty and inequality (SDG1, 10). We call attention to the 'elephant in the room'- the failure to go beyond GDP but instead include economic growth as a goal (SDG8). We argue that sustainable degrowth and intersectional decolonial environmental justices would create better conditions for the transformative changes needed to reach the broader aim of the SDGs: to leave no one behind.
\end{abstract}

Keywords Injustice $\cdot$ Just sustainability $\cdot$ Environmental justice $\cdot$ Social justice $\cdot$ Intersectionality $\cdot$ Decoloniality

\section{Introduction}

In 2015, the United Nations launched the 2030 Agenda for Sustainable Development, which outlines 17 Sustainable Development Goals (SDGs) (UN 2015) (Table 1). The

Handled by Joseph Alcamo, University of Sussex, United Kingdom.

\footnotetext{
Mary Menton

mcsmenton@gmail.com

1 Sussex Sustainability Research Programme, University of Sussex, Brighton, UK

2 Simón Bolívar Andean University, Quito, Ecuador

3 Latin American Faculty of Social Sciences, Quito, Ecuador

4 Autonomous University of Barcelona, Barcelona, Spain

5 McGill University, Montreal, Canada
}

SDGs have been the subject of extensive research, political support, and civil society engagement but also critique. Some point out that they are a marked improvement on the Millennium Development Goals (MDGs), both in terms of the role of civil society in contributing to their creation and in transitioning from including the environment in only one goal (MDG 7, Environmental Sustainability) to integrating environmental targets into each of the goals (see discussion in Omisore 2018). The SDGs are intended to be more integrated and produce synergies, but the interactions among them also lead to trade-offs. One study of interactions amongst the SDGs, based on a time-series of data reported by countries, found that the number of synergies outweighed the trade-offs (Pradhan et al 2017). Yet, as Nilsson et al (2016) show in their framework for assessing trade-offs and synergies among the SDGs, the magnitude and direction of the interaction can vary between countries, dependent on national circumstances. 
Table 1 Sustainable development goals

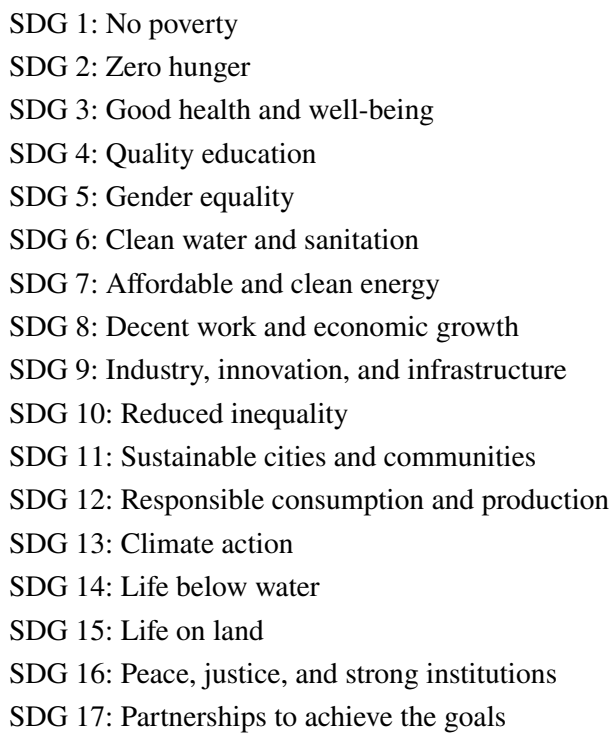

The SDG framework has been questioned by many (Washington 2015; Kopnina 2016). In his discussion of the fallacies of the SDGs, Easterley (2015) argues that the inclusion of weak language and "escape clauses" creates a situation in which the only thing that all the authors could agree on "was that the SDGs did not actually bind them to anything" (p 323). In many instances, the SDGs fail to combat the global economic and geopolitical systems that create gender and other injustices in the first place (O'Manique and Fourie 2016; Kopnina 2016). Although the 2030 Agenda document (Transforming Our World-TOW) speaks of transformation, we argue that it will not be possible to achieve a "win win" when the very systems which create poverty, hunger, inequalities, and unsustainable development are upheld. These win-wins are not achievable against a sustainable imaginary, given the oxymoron of 'sustainable growth' (Bartlett 1994).

As O'Neill et al. (2018) found: no countries currently meet all the needs of its populations at globally sustainable levels of resource use. As global population increases, the tendency to overshoot these boundaries will increase if rates of consumption are not reduced. The Sustainable Development Index created by Hickel (2020) evaluates the environmental sustainability of the production and consumption models of different countries. Many of those furthest along towards meeting the SDGs (e.g., Norway, UK) are amongst the worst in environmental sustainability. As such, there are in fact many potential contradictions between the SDGs and environmental justice (EJ) and the human right to a healthy environment.

States have the legal obligation to protect against violations of the human right to a healthy environment (Knox and Pejan 2018), and human rights violations arising from climate change (Knox 2009). In light of recent rulings by human rights tribunals that assert States' obligations to protect human rights that are compromised by environmental harm, Knox (2015) found that the language of the SDGs was "neither concrete nor closely linked" to these obligations. These environmental human rights are closely linked to EJ, particularly in the Global South (Adeola 2000; Agyeman et al. 2002). Although some authors point to philosophical problems underlying the human rights paradigm (Mutua 2013; Barreto 2014) and particularly related to the link between human rights and EJ (Woods 2006), the embeddedness of human rights within international policy arenas could provide impetus in support of EJ which could improve justice outcomes for both humans and non-humans. In seeking the protection of environmental rights, progress has also been made towards recognising the rights of nature and protecting non-human species. For example, Colombia's Supreme Court recently recognised the rights of the Amazon River ecosystem (STC4360-2018). Ecocide, the large-scale and systematic destruction of nature, has been proposed for inclusion as criminal offense in international criminal courts (Higgins 2012).

We do not assume that 'sustainable development' and 'environmental justice' are synonyms given that they are concepts that arise from different schools of thought with priorities that are not always consistent. While sustainability often focuses on policy-making at multiple scales aimed at intergenerational equity (protecting the needs of future generations), EJ has tended to focus on local, present-day policies and power asymmetries that disproportionately burden particular groups (Agyeman et al 2002). Sustainability agendas have arisen from top-down policy processes, whereas EJ, in contrast, arises from grassroots responses to environmental racism (ibid). As Agyeman and Evans (2004) assert, justice and equity are "at best implicit" in the Brundtlandt report and IUCN definitions of sustainable development. The authors propose the need for 'just sustainability', "a balanced approach including an explicit focus on justice, equity and environment together" (Ibid, p 157).

"Transformative sustainability or just sustainability implies a paradigm shift that in turn requires that sustainability takes on a redistributive function. To do this, justice and equity must move centre stage in sustainability discourses, if we are to have any chance of a more sustainable future." (Agyeman 2008, p 752)

The SDGs fail to incorporate an explicit justice focus and EJ is largely absent from the goals, targets, and indicators. In this paper, we address this gap. We part from the assertion that "many 'environmental' problems are, by their very nature, problems of justice" (Lele 2017), and that given the interactions among the different targets and indicators 
thereof, the implementation of the SDGs may have negative consequences for EJ.

Drawing on multiple disciplines, in particular economics, conservation science, political ecology, anthropology, geography, political theory, and law, we provide an overview of frameworks and conceptualisations of EJ and framing of justice within the SDGs. We argue for the importance of a decolonial and intersectional approach to EJ (Intersectional Decolonial Environmental Justice). Herein, decoloniality stands in contrast to the current colonial paradigm and means "working toward a vision of human life that is not dependent upon or structured by the forced imposition of one ideal of society over those that differ" (Mignolo 2007, p 459). Intersectionality, as per Crenshaw (1989, 1991), asserts that the combination of different aspects of an individual's identity can create distinct forms of discrimination and injustices.

By focusing a sub-set of the SDGs, we highlight the gaps and/or contradictions in particular SDGs but also the interactions among SDGs for the Food-Water-Health Nexus (SDGs 2, 3 and 6), climate and energy (SDGs 7 and 13), poverty and inequality (SDGs 1 and 10), and environmental conservation (SDGs 14 and 15). Amongst other important trends, we emphasize the contradictions inherent in promoting environmental sustainability within a framework that promotes GDP growth (SDG 8) and operates within a neoliberal capitalist system that values consumption and growth often at the expense of environmental sustainability. We use case studies of ecological distribution conflicts (see Scheidel et al. 2018) highlighted by the environmental justice atlas (https://www.ejatlas.org, see Temper et al. 2015) relevant to these SDGs to elucidate the potential for EJ frameworks to support the transition towards just sustainability. We argue that $\mathrm{EJ}$ is a prerequisite for the transformation towards sustainability. Without multi-scalar intersectional decolonial EJ that protects the rights of current and future generations from local to national to global scales, sustainability, and achievement of the SDGs may indeed be impossible.

\section{Environmental justice frameworks}

The concept of Environmental Justice gained traction in the early 1980s when poor, mostly African-American rural communities mobilized against a hazardous waste dump being built near their homes in North Carolina, USA. These mobilizations led to a series of landmark studies that showed the unjust distribution of polluting activities that was affecting disproportionately lower income households and communities of colour in the US (Bullard 1993). This struggle marked the emergence of a new type of movement where environment, anti-racism, and civil rights concerns were brought together (Bullard 1990; Pulido 1996). In essence, an intersectional socio-environmental movement.

While EJ was in the beginning prominently related to the inequitable distribution of waste and pollution, the term has come to address a broad number of substantive problems, struggles, and aspirations. In 1991, the First National People of Colour Environmental Leadership Summit held in Washington DC issued the document "Principles of Environmental Justice". The document highlighted 17 principles that illustrate the wide scope of EJ, including: affirmation of the sacredness of Mother Earth and the right to be free from ecological destruction; affirmation of peoples' right to self-determination; demands for rights of participation and enforcement of principles of informed consent; as well as rejection of military occupation, repression and exploitation of lands, peoples, and cultures, and other life forms. The Principles explicitly refer in their Preamble to the need to begin to build a "national and international" grassroots movement for EJ. They include considerations on environmental injustices facing the current generation but also to future generations and other species, or non-humans.

Debates on how we can define global EJ (Schlosberg 2013; Martinez-Alier et al. 2016; Sikor and Newell 2014) have made productive contributions regarding the dimensions of justice and inequality across locations and the global trans-national institutions and interconnections that join them, highlighting the plurality of justice norms across diverse cultural, social, and environmental contexts (Temper 2018).

During the past 3 decades, EJ terminology has spread spatially and evolved temporally, embracing new political meanings, aspirations, and dimensions in different contexts (Holifield et al. 2018). In addition to engaging with its multiple definitions, scholars have increasingly addressed and theorised the multidimensionality of justice in EJ (Walker 2009; Schlosberg 2007; Holifield et al. 2018). Below, we outline key pillars of (1) mainstream EJ, (2) critical EJ; (3) ecological justice; (4) abolitionist and decolonial EJ; and (5) intersectional decolonial EJ. These different frameworks build upon each other, with a general shift over time towards a more complete framing of EJ that fully recognises power dynamics and the need to account for the complexity and intersectionality of injustices while recognising the different epistemologies of, and visions for, justice originating from both theory and action in the Global South.

\section{‘Mainstream' environmental justice}

Although some have labeled it 'radical environmental justice' (Svarstad and Benjaminsen 2020), the most 'mainstream' framework of EJ is that which adheres to the four dimensions: (1) distributional justice, (2) recognitional justice, (3) procedural justice (e.g., participation, 
decision-making), and (4) the capabilities approach (Fraser 1995, 1998; Schlosberg 2007; Young 1990). As Schlosberg (2007) points out, justice, in political practice, is articulated and understood as a balance of numerous interlinked elements of distribution, recognition, participation, and capability.

\section{Distributive justice}

Distributive justice (DJ) focuses on the fair distribution of environmental costs and benefits, the allocation of material goods, such as resources, income, and wealth, or on the distribution of social standing. This paradigm has led to a prolific body of theoretical and empirical research. However, it has been claimed that such perspective neglects the relevance of the social structure and the institutional context in distribution patterns. Iris Young (1990) highlights the role of power, decision-making procedures, division of labour, and culture in influencing EJ. The processes construct the material maldistribution (Honneth 2001; Walzer 1983; Young 1990).

\section{Recognitional justice}

Recognitional justice (RJ) is the recognition of, and respect for, difference. It has been underlined as a key dimension of justice (Young 1990; Fraser 1998; Schlosberg 2007; Honneth 2001; Holifield et al. 2018). According to Fraser (1995), while the 'redistribution' concept is tied to a vision of justice that aims to achieve social equality through a redistribution of the material necessities for existence as free subjects, in the case of 'recognition', the conditions for a just society are defined as the recognition of the personal dignity of all individuals. Recognition refers not only to the individual right to self-recognition (Honneth 2001), but, most importantly, to the recognition of collective identities and their particular concerns, needs, and livelihoods in relation to nature and the environment.

\section{Procedural justice}

Procedural justice (PJ) addresses the fair and equitable institutional processes of a State. In this approach, justice requires not only an understanding of unjust distribution patterns and the lack of recognition, but, mainly, an understanding of the ways in which the two are tied together in political and social processes (Cole and Foster 2001; Schlosberg 2007). When "patterns of disrespect and disesteem are institutionalized" (Fraser 1998), participatory inequities or exclusions (Agarwal 2001) appear in institutions and decision-making processes.

As pointed by Bell and Carrick (2017), one of the reasons for the unfair distribution of environmental burdens and benefits is that the decisions that transform the environment are usually made by people who enjoy the benefits rather than the burdens. Historically, the institutions that make the decisions that affect the environmental conditions of our lives, from the local to the global, have excluded or marginalised people. Currently, gross inequalities of political authority, power and influence, remain the norm in environmental decision-making, leading to procedural environmental injustice (Bell and Carrick 2017).

\section{Capabilities approach}

The capabilities approach views justice not simply based on the distribution of various goods (e.g., natural resources or environmental services), but on how they link to an individual's capacity to flourish (Schlosberg and Carruthers 2010). The capabilities approach builds on the capability approach (Sen 1999; Nussbaum 2011). Schlosberg and Carruthers (2010) describe the capability approach as "capacities necessary for people to function fully in the lives they choose for themselves." The capability approach focuses on the multi-dimensional aspects of well-being, focusing on the freedoms that come from capabilities instead of merely the outcomes (Roybens 2005).

\section{Critical environmental justice}

More recently, the Critical Environmental Justice (CEJ) framework (see Pellow 2018) has called for an expansion of EJ beyond the aforementioned dimensions, critiquing the tendency of EJ literature to focus on state/institutional reforms or policy concessions that do not change the power structure that produce environmental injustices. According to Pellow (2018), EJ must be more deeply critical of these power structures and the multi-scalar complex nature of EJ. He proposes four pillars.

1. Intersectionality: recognises that "social inequality and oppressions in all forms intersect" (Pellow 2018, p18). It highlights the common thread of domination and othering practiced by other more powerful groups (Pellow 2016).

2. Multi-scalar approaches: CEJ aims to take a multi-scalar approach understanding the complex spatial and temporal causes, consequences, and possible resolutions of EJ struggles.

3. Embeddedness: social inequalities are deeply embedded in society and reinforced by state power

4. Indispensability: excluded, marginalised and othered populations, both human and non-human beings and things, are indispensable.

CEJ moves beyond the anthropocentric focus of mainstream EJ to include justice non-human beings (Pillar4). 


\section{Ecological justice}

Some authors argue that EJ tends to be anthropocentric, and support the need for 'ecological justice' - a justice wherein non-human species have a claim to justice (Baxter 2004). Kopnina and Washington (2020) argue that environmental justice is "justice for humans in regard to environmental issues... quite different from ecological justice, which is about justice for nature" (p8). They argue that the historic tendency to prioritise social justice over ecological justice must be reversed considering the current state of environmental degradation and species loss. Even so, they call attention to the interdependence between the two, that "justice for both humans and non-humans and their habitats can only be achieved simultaneously" (Kopnina and Washington 2020, p 4). Differentiation between the focus on justice for nature and non-humans (ecological justice) and a focus on social justice in relation to environmental issues (environmental justice) is still salient in much of the theoretical and empirical work on environmental justice. However, CEJ includes an emphasis on the non-human in the pillar of indispensibility, effectively blurring of the distinctions between environmental and ecological justice. In the literature on abolitionist and decolonial environmental justice (see below), this distinction is also blurred, reflecting different imaginaries and cosmovisions that do not view humans and the natural world as separate entities. As such, while some applications of environmental justice are indeed anthropocentric, we argue that many EJ frameworks do, and rightly should, call for justice for people and nature.

\section{Abolitionist and decolonial environmental justice}

Some scholars propose the need to move towards decolonial EJ (Álvarez and Coolsaet 2018) and an EJ that draws on abolitionist and decolonial theory (Pulido and De Lara 2018). Abolitionist theory calls for an end to racism and racial capitalism that exploits people of colour. It seeks to "abolish the same racial and capitalist relationships of power that produced the colonial project of plunder and dispossession" (Pulido and De Lara 2018, p 78). As mentioned earlier in the text, decoloniality focuses on counteracting the impacts of coloniality of power (Quijano 2007) and the subjugation of peoples and knowledge systems that take place within colonial systems (past and present). Alvarez and Coolsaet (2018) criticize the tendency of EJ work to be theorised under Western norms, while the research is applied in the Global South. As such, despite a focus on justice, the analytical frameworks can further domination and misrecognition, because they fail to account for the perspectives and desires of majority-world groups (Svarstad and Benjaminsen 2020). In essence, they cause 'epistemic violence' by emposing frameworks which do not reflect local epistemologies (Vermeylen 2019). Pulido and de Lara (2018) call for a reimagined EJ framework based on the radical epistemic traditions of activists which go beyond the rights-based approaches that focus on recognition and redress of wrongs by a liberal state (which thereby validates the very systems of oppression). They call for a framework that includes the desires of abolitionist and decolonial traditions. Temper (2019) argues for a decolonial EJ that moves beyond mainstream EJ, such that "rather than simply participation, justice must include self-governing authority; that rather than distribution (of nature), EJ calls for breaking down the dualism between humans and nature, and beyond recognition, what is needed is epistemic justice and self-affirmation" (p 104).

\section{Towards a more intersectional decolonial framing of environmental justice (IDEJ)}

Intersectionality asserts that the combination of different aspects of an individual's identity can create distinct forms of discrimination and injustices. Emerging from black feminist theory, intersectionality emphasizes the "need to account for multiple grounds of identity when accounting for how the social world is constructed" (Crenshaw 1991). "Intersectional subordination need not be intentionally produced; in fact, it is frequently the consequence of the imposition of one burden that interacts with preexisting vulnerabilities to create yet another dimension of disempowerment." (Crenshaw 1991, p 1249).

Malin and Ryder (2018) call for a deep intersectional approach to EJ scholarship though studies that "(1) emphasize multiple social locations and intragroup differences; (2) explore these issues with a multi-scalar lens; and (3) more directly and critically identify and analyse not only powerful actors but systems and processes of power in these dynamics." We argue for the need to incorporate different imaginaries of justice within an intersectional decolonial EJ that addresses the power dynamics that lead to injustices that come from many directions, and works to redress the racial capitalist system embedded within the colonisation of spaces and bodies, both human and non-human. A transition towards just sustainability would require the merging of traditions of CEJ, decolonial EJ theorised by the periphery/south that focuses on social and ecological justice for humans and non-humans and recognises power dynamics, and the complexity of intersectionality of marginalisations and injustices. Transformations towards just sustainability would be strengthened if the SDGs recognised the intersectionality of social, environmental, and ecological injustices which increase the interactions between the SDGs and fostering both synergies and trade-offs amongst them. 


\section{Framing of justice within the SDGs:}

"The new Agenda recognises the need to build peaceful, just and inclusive societies that provide equal access to justice and that are based on respect for human rights (including the right to development) on effective rule of law and good governance at all levels and on transparent, effective and accountable institutions. Factors which give rise to violence, insecurity and injustice, such as inequality, corruption, poor governance and illicit financial and arms flows, are addressed in the Agenda."

(UN 2015, Transforming our World: the 2030 Agenda for Sustainable Development, $p$ 12)

The SDGs are highly relevant to environmental and social justice, and vice versa. However, as with earlier definitions of sustainable development (see Agyeman and Evans 2004), the SDG document Transforming Our World (TOW), and the SDG targets and indicators (UN 2017), do not address justice directly in most of the goals. Even though one of the SDGs centres around Justice (SDG 16: Promote peaceful and inclusive societies for sustainable development, provide access to justice for all and build effective, accountable, and inclusive institutions at all levels), it does not address EJ and the term justice is not defined. SDG16 refers to rule of law, issues around human rights and legal justice in general, without attention to procedural justice or recognition within the 'justice' SDG (SDG16).

SDG 16 places emphasis on the 'rule of law' $(16.3,16.9)$, with a reference to international human rights (16.8.1) and an approach to accountability and transparency that prioritizes the eradication of state-based corruption $(16.5,16.6)$ (McDermott et al. 2019). This focus "largely bypasses the difficult question of how state definitions of justice inevitably privilege some actors and some conceptions of justice over others." (McDermott et al. 2019). As such, while it is the 'justice' SDG, its narrow conceptualisation of justice fails to address the power dynamics and structural conditions that impede environmental and social justice and, therefore, constrains its ability to support EJ. This is particularly true for countries that do not recognise legal rights to a healthy environment, land, and even food (see discussion below on SDG2).

SDG 16 frames its focus on 'peace' and physical violence. It includes one mention of psychological violence (indicator 16.1.3), but does not take into account other forms of violence nor concepts of EJ or social justice. A report on killings of human rights defenders identified 321 murders in 2018, 77\% of which were defending environmental and/ or land rights (Front Line Defenders 2019). In some cases, the State is complicit in the violence against EJ activists. These killings represent the tip of an iceberg of violence linked to resource extraction and economic growth (Butt et al 2019): many more people suffer from slow violence (see Nixon 2011), structural violence (Farmer 2004), and psychological violence through threats and other forms of intimidation (Global Witness 2018). As described in Temper et al (2015), the Environmental Justice Atlas documents over 3000 ecological distribution conflicts globally which point to slow violence via environmental degradation (see Nixon 2011), changes in social metabolism, and effects on local livelihoods. Yet, these types of conflicts, violences, and environmental injustices are not addressed directly by the SDGs.

Beyond the narrow scope of SDG16, the terms just/ justice/injustice only occur 12 times in the TOW 41 page document. The terms related to distributive justice occur frequently throughout the text: inclusive (46) equity (14) and equality (41) are more prevalent, as are access (58) and procedure is reflected in some attention to questions of participation (16). Rights are mentioned 23 times. The use of language around justice framed as human rights and legal justice reflects the state-based focus of the policy development process: while the SDGs did go through consultations with civil society and stakeholder groups, the final decisions regarding language and inclusion/exclusion of targets and indicators were made by State actors.

\section{Synergies, gaps, and contradictions: EJ and the SDGs}

Given the absence of an explicit justice framing of the SDGs overall framework, it becomes essential to unpack the interactions within and among the different SDGs and their targets and indicators. For some cases, synergies emerge, such that implementation of particular SDGs is highly likely to have positive outcomes for EJ. We use the food-water-health nexus as an example. In others, substantial gaps and flaws exist, such that implementation of the SDGs could have both negative and positive implications for EJ [climate \& energy justice (SDG7 \& SDG13), conservation SDGs (SDG14 \& SDG15), and poverty \& inequality (SDG1 \& 10)]. Finally, we look at the inclusion of economic growth (SDG8) as an explicit goal and how it leads to outright contradictions of EJ that exacerbate the gaps highlighted in the other SDGs.

\section{Food-water-health nexus (SDG2, 3, and 6)}

There are clear synergies and interactions between SDG2 (Hunger), SDG3 (Health), and SDG6 (water). Food and nutrition security, together with access to clean water and related sanitation, are prerequisites for health. In fact, water is central to many of the SDGs, including its role in meeting 
the goals linked to agriculture (SDG2), industry (SDG12), and conservation of freshwater ecosystems (SDG15) (Mugagga and Nubaasa 2016).

The framing of SDG 6 moves beyond the MDGs focus on sanitation and drinking water to include decreasing water pollution, decreasing water use, and protecting water-based ecosystems. However, as Lele (2017) points out, the targets focus largely on availability (DJ) and fail to create space for consideration of intragenerational considerations (CEJmulti-scalar) and procedural justice.

The Lancet commission on pollution and health found that $16 \%$ of global deaths are caused by pollution, for countries most severely affected, that rises to $25 \%$ (Landrigan et al 2018). Given this link to environmental conditions, health is an environmental issue and has direct links to EJ. The SDG3 targets speak to water-borne diseases (3.3) and deaths from water (and air, soil) pollution (3.9). Although the health SDG is often framed as a social one, it is particularly relevant to EJ given the history of the EJ movement, which arose out of the fight against the disproportionate burden of pollution and waste borne by poor black communities in USA (and later elsewhere). At the global scale, communities in low-income countries are more likely to suffer the ill effects from pollution linked to factories and extractive industries that provide resources and goods for consumption in high-income countries. As such, health impacts of environmental degradation are a distributive justice issue with particularly multi-scalar implications and intersectional manifestations of injustices linked to colonial pasts (and presents) (IDEJ).

While the TOW, which serves as a SDG roadmap, recognises the right to clean water, health, and education, the right to food and nutrition is not explicitly included in the language of the SDGs-instead, they assume that market mechanisms will lead to food security (Vivero Pol and Schuftan 2016). In part, the absence of recognition of access to food as a right is linked to opposition by countries, like USA, who do not see food as a right despite recognition of such in the Universal Declaration of Human Rights (see discussion by Vivero Pol and Schuftan 2016). This framing of food as a commodity and not a prerequisite to life itself is clearly in contradiction to distributive justice as well as CEJ's concept of injustice that acts as if particular populations are expendable, in this case poor and marginalised peoples who are food insecure. People in the majority world suffer disproportionately from these injustices, with national and regional manifestations of racism and sexism creating a particular burden on minorities and women (IDEJ).

Three of the SDG 2 targets are of particular relevance to EJ. Target 2.3 aims to "double the agricultural productivity and incomes of small-scale food producers, in particular women, indigenous peoples, family farmers, pastoralists, and fishers, including through secure and equal access to land, other productive resources and inputs, knowledge, financial services, markets and opportunities for value addition and non-farm employment." The explicit mention of the importance of equal access to land and resources links to distributive justice. Target 2.4 , which focuses on agriculture in general (in contrast to the small-scale producer focus of 2.3), seeks to increase productivity whilst maintaining ecosystems and climate-change adaptability (in essence, sustainable climate smart agriculture). While it calls attention to the environmental impacts of agriculture, it fails to recognise the power relations and structures within the agricultural sector that exclude the poor from equitable benefit from that production (DJ; IDEJ). Target 2.5, which addresses seed banks and genetic resources, concludes that it must "promote access to, and fair and equitable sharing of, benefits arising from the utilization of genetic resources and associated traditional knowledge". While this target focuses largely on DJ ('sharing of benefits'), by highlighting the role of traditional knowledge, it is a rare example of inclusion of recognition (RJ) and a potentially a decolonial perspective that values traditional knowledge.

\section{Case-study: applying EJ to the food-water-health SDG nexus}

Cruz (2017) documents the story of the Tuxá of Northeastern Brazil who suffered numerous injustices linked to the Itaparica dam, built along the São Francisco River in Bahia, Brazil in the 1980s. Although built long before the SDGs were in place, similar dams are currently being proposed and justified, in part, for their contribution to sustainable development. The dam aimed to create both hydroelectricity (SDG7) and supply water for irrigation (SDG6.5) in semi-arid areas of Brazil's northeast (SDG2.3, 2.4). The dam flooded $834 \mathrm{~km}^{2}$ of land (SDG15) and displaced thousands of families, including the Tuxá indigenous peoples who had lived on the islands in the river and whose ancestral lands, burial grounds, and sacred sites were suddenly submerged (RJ, DJ, CEJ-indispensibility, IDEJ). The Tuxá families faced coercive negotiation processes $(\mathrm{PJ})$ and were resettled in a condominium style village in nearby Rodelas town (RJ). They were promised agricultural lands that never materialised, suffering in turn from cultural loss, mental anguish and health problems over the 3 decades which they have been in resettlement village (RJ, CEJ-intersectionality, CEJ-multi-scalar, IDEJ). While the benefits accrue to industries and large-scale farmers away from the river, the costs were borne by the Tuxá (DJ, CEJ-multi-scalar). The complexity of the conditions and the impacts that these projects cause could be better understood, and environmental injustices avoided, through the evaluation of projects through the lens of an EJ framework that could promote just sustainability and avoid repeating these multiple injustices and human rights violations. 


\section{Affordable and clean energy, and climate (SDG 7 \&} 13)

Justice issues regarding climate and energy topics have been generally framed in terms of "climate and energy justice" respectively, both in the academic and civil society domains (Heffron and McCauley 2017; Jenkins 2018; Jenkins et al. 2016; Schlosberg and Collins 2014; Sovacool and Dworkin 2015). However, both terms share overlapping philosophical groundings with the EJ framework. Thus, we use the term EJ to discuss climate and energy-related SDGs from a justice perspective.

These two SDG goals explicitly recognise their interrelations as anthropogenic climate change is principally caused by the greenhouse gas emissions (GHG) coming from the use of fossil fuels within our current socio-economic system (energy, transport, industry, and residential and agri-food systems). Transitions to clean socio-technological energy systems have the potential to build communities that are more inclusive and resilient to climate change.

The overall SDG framework acknowledges that energy and climate are necessary conditions for achievement of social justice and other developmental goals. However, they frame energy and climate challenges (causes and solutions) in a very narrow way that mainly addresses some aspects related to DJ. Whereas the climate problem is framed as a problem of excessive GHG emissions and of adaptation to climate-related extreme events that can be solved through technological change and voluntary international agreements (mainly the United Nation Framework Convention on Climate Change-UNFCCC), the "energy question" is reduced to a problem of decarbonization of energy sources and energy poverty.

Regarding climate change, the main DJ aspects that SDG13 acknowledges is both the inequitable contribution to anthropogenic climate change and the inequitable distribution of its impacts. This has been mainly translated into financial transfers and assistance targets (sub-goals 13.A and 13.B) from the Global North (those most responsible for the injustice of climate change) to the Global South (those most vulnerable) based on historical responsibility. These measures can be understood as compensatory or corrective justice. However, this historical responsibility on the part of advanced industrialized countries is no longer applied to future GHG emissions cuts, because since Paris Agreement (2015), GHG target, and timeline reductions are voluntary instead of mandatory for signatory states. It is important to acknowledge that despite the many shortcomings of the Paris Agreement, in terms of distributive and procedural/participative justice, it exhorts for the first time that emergent countries (e.g., China, India, Brazil, etc. that are nowadays top GHG emission countries (in absolute but not in per capita terms) assume GHG cuts responsibilities. Furthermore, it takes into consideration more explicitly non-state actors' GHG cuts emissions. Yet, climate-change policy regimes have emerged under, and reflect, background circumstances of serious injustice (colonialism and current trade rules) that many question its ability to deliver climate justice (Savaresi 2016; Spash 2016). In this regard, despite the fact that SDG13.A appeals for "meaningful mitigation actions", UNFCCC's flexible mechanisms (mainly CDM, carbon markets, and REDD +) are criticized for being giveaways to polluters at the expense of vulnerable social groups and for ineffective measures in terms of emissions reductions (Aldred 2012; Chomba et al. 2016; Forsyth 2014; Godden and Tehan 2016; Lohmann 2004; Schlosberg and Collins 2014). Furthermore, UNFCCC's state-led adaptation policies have been seen mainly as reducing impacts of physical events such as floods and storms rather than more development-oriented approaches such as diversifying livelihoods options of vulnerable regions and social groups (Schlosberg and Collins 2014). This is also reflected in SDG 13.1 (resilience and adaptive capacity) and might be the result of procedural and recognition injustices in which states mainly participate in the design of these strategies. Therefore, what is considered as climate risks and the identification and prioritization of adaptations measures is derived from states' priorities and interests in detriment of vulnerable social groups' views, values and human rights. Finally, this specific view on adaptation entails that the unequal exposure to climate risks is not contested as long as vulnerable people adapt to it.

SDG 13 acknowledges the need of a rapid transition to a low-carbon version of the current socio-economic system based on renewable technologies and efficient energy measures. Yet, it is silent on limiting fossil-fuel extraction and production. These low-carbon aims are specifically targeted in the SDG 7.

Despite the fact that energy injustice (at different scales and domains) is predominant in our current socio-technological energy system, SDG7 only recognises some energy distributive and recognition injustices in its end-use stage. It mainly refers to issues of energy poverty (inability to attain a socially and materially necessitated level of domestic energy services) and energy vulnerability (the risk of suffering from an enforced lack of such services and/or negative impacts associated with polluting energy services). These energy poverty and vulnerability situations tend to affect disproportionally particular social groups (mainly elderly, chronically ill, women). SDG 7.1 and 7.2 aim to overcome this situation by fostering universal affordable, modern (best available energy technology), reliable (security in the supply), and efficient energy. Regarding the latter issue, it is not only important to achieve a relative dematerialization (reduction in consumption) as SDG 7 promotes, but also an absolute dematerialization which it does not address. An increased 
energy demand as current trends show warrants greater and faster production, which, in turn, creates "production sacrificed zones and vulnerable social groups" (Hernández 2015). This applies both for fossil-fuel energy sources and renewable ones. Therefore, increasing the renewable energy share in the global energy mix (SDG 7.2) might reproduce and indeed further existing injustices in the supply side. As McCarthy (2015) contends, renewable energies are less dense than fossil fuels, so they are more spatially extensive. New production space is needed that would disproportionately affect rural areas where land values are lowest and fewer formal land rights exists. Furthermore, previously free and common natural resources (wind, sunlight, waves, and heat of the earth) will be privatized, which, in turn, can trigger new primitive accumulation processes (IDEJ).

SDG 7 focuses exclusively on the material domain (physical infrastructure) of the current socio-technological energy system, but remains mainly silent on the social (user practices and meanings, lifestyles, business models, markets, power, etc.) one. Unequal structures of ownership and control of energy are unrecognized and consumerist aspirations of the vast majority are under recognised. These issues are related with procedural and recognition aspects of justice (Heffron and McCauley 2017; Jenkins 2018; Sovacool and Dworkin 2015). On one hand, to grant citizens' energy choices about production and use, and their sufficient control over consumption and energy costs, due processes, information disclosure, transparency, accountability and free, prior and informed consent are necessary conditions. On the other, conscious and democratically elected commitments to energy transitions based on low consumption and renewable resources (bottom-up processes) tend to be more long-lasting and fair (recognition justice) than top-down approaches (Akizu et al. 2017). To sum up, changes in the energy regime must address inequalities in power and injustices across the entire socio-technological system (IDEJ).

\section{Case study: applying the EJ framework to the climate and energy SDGs}

Wind farms in Oaxaca, Mexico have created extensive conflicts with local communities (see EJAtlas 2017; Avila 2018; Dunlap 2018, 2019). The wind farms are 'sold' as a means to produce renewable energy (SDG7.2) as part of 'green economy' initiatives that would reduce GHG emissions (13.a) and provide jobs (SDG1, SDG8), yet they exacerbated existing problems and inequalities (SDG1, SDG2, SDG10) (CEJ-intersectionality, IDEJ). In this case, indigenous people and subsistence farmers and fishers have borne the costs (DJ, CEJ-intersectionality, IDEJ) of wind farm projects arising from State supported private companies controlling large tracts of land (and sea) (CEJ-embeddedness) and excluding them from their ways of life and 'spiritual sustenance' some communities gain from the sea (RJ, CEJ-indispensability) (Dunlap 2018). FPIC and consultation processes were delayed and embedded within state-corporate power dynamics (PJ, CEJ-embeddedness). This case highlights the importance of applying an EJ framework prior to installation of projects that may appear 'green', yet can lead to multiple environmental injustices upon installation.

\section{The ‘Conservation’ SDGs (SDG 14 \& 15)}

SDG 14 (Life Below Water) and 15 (Life on land) outline actions required to address pollution, overexploitation of species, and habitat degradation and loss. Both SDG 14 (Life below water; 'recognizing [...] differential treatment for developing and least developed countries') and SDG 15 (Life on land; 'Access and benefit sharing') recognise issues of inequality in 'distribution', but provide no clear guidance to address potential issues associated with 'procedure' or 'recognition'. The SDGs' frame environmental concerns with an anthropocentric bias: encompassing those that are related to natural resource consumption and meeting human needs (Kopnina 2016). In the face of a 'genocide of non-humans' (Crist 2012), Kopnina (2016) asserts that the required next step, beyond pushing for $\mathrm{EJ}$ and $\mathrm{SD}$, is a transition towards 'inclusive ecological justice' that recognises the needs of other species. As we highlight above, intersectional decolonial EJ would acknowledge the indispensability of non-humans as well as marginalised peoples. It would recognise the need for ecological justice as a prerequisite to EJ and just sustainability.

Many of the drivers affecting wildlife and ecosystems can be attributed to growth in social metabolism that support economic growth (SDG 8). Some of the main drivers of environmental degradation are the extractive industries which are addressed, at least in part, by SDG12 (sustainable consumption), yet contradictions arise with the promotion of economic growth (SDG8) which would increase consumption. PJ, RJ, and IDEJ injustices often result from expansion of these sectors.

Disproportionate burdens of the negative consequences of this degradation are shouldered by marginalised communities (DJ) which impacts their access to clean water (SDG6), their health (SDG3), access to land for agriculture (SDG2), and, therefore, loss of livelihoods (SDG1). In this sense, there are synergies between the conservation SDGs $(14,15)$ and those linked to health, water, and livelihoods.

However, it should also be recognised that EJ conflicts can be driven by measures to protect threatened species, ecosystem services, and environments, particularly where policies impact poor or social and cultural minorities (Suich et al. 2015). They have the potential to create justice for nature (conservation and protection of non-human species) while simultaneously creating environmental injustices for 
people. The wording of SDG 14.5 that states that 'by 2020 , [governments must] conserve at least $10 \%$ of coastal and marine areas, consistent with national and international law and based on the best available scientific information' has the potential to generate environmental injustices if marine protected areas fail to consider the livelihood, food security, and EJ impacts to local or indigenous peoples. The creation of parks and exclusion zones may bring progress towards SDG14 and SDG15, yet simultaneously create justices and injustices to different groups of people and impact on the most basic needs and rights of some of the most vulnerable and poor (Sikor 2013).

Conservation often aims to limit human activity in areas of high biodiversity that tend to be located in lower income countries (Myers et al. 2000) and displaces already marginalised families from their lands and/or limits their access to the traditional hunting grounds. As a consequence, a power imbalance exists as mainstream conservation is dominated by technical capacity from the north that can result in imposition of culturally bound visions of natural resource management on local and indigenous peoples (IDEJ). Resulting environmental injustices have included cultural destruction, forced relocation, impoverishment, and the undermining of traditional systems of natural resource management (Colchester 2003).

In attempts to use the power of the state over resources at the expense of indigenous groups, some mainstream conservationists make explicit political choices to work with states (CEJ-embeddedness). Processes of 'green militarisation' and related 'green violence' are found where conservation has been militarised and guns and other forms of force are used in the name of conservation (Buscher and Ramitsundela 2015; Marijnen and Verweijen 2016). In fact, in some cases, there has been an alliance formed between global security interests and conservation, in essence forming a 'war by conservation' which uses a 'poachers-as-terrorists' to justify these alliances (Duffy 2016). Human rights abuses have been reported with repressive state agencies, and even NGOs abusing power in the name of conservation (Bluwstein and Lund 2018; Warren and Baker 2019). Despite these tensions, new framings of conservation argue for post-capitalist 'convivial conservation' that promotes radical equity, structural transformation, and EJ (Buscher and Fletcher 2019). Such a model of conservation could promote IDEJ.

\section{Case study: EJ frameworks and conservation SDGs}

The establishment of the Bwindi Impenetrable National Park in Uganda in 1991 protects over half of the global population of mountain gorillas. The region has a rich human history with evidence of cultivation by the local Batwa people dating from over 4800 years ago. A significant degradation in the twentieth century resulted in designation as a
National Park in 1991 under control of the Ugandan Wildlife Authority (UWA). The fortress conservation approach taken resulted in exclusion of remaining Batwa (pygmy) from the park in 1992 and strict laws that punished extraction of forest, drastically impacting on the mostly forestdependent Batwa communities in the area (EJAtlas 2019). Many evicted Batwa never received compensation or alternative land (DJ). Those that resettled in agricultural land bordering the park have suffered crop raiding from wildlife, making agriculture difficult to maintain, with loss of access to forest timber and resources compounding their situation (Martin et al. 2015). Those that resettled have also suffered discrimination impacting human rights, educational opportunities (SDG4), health (SDG3), and jobs (SDG8, SDG1) (Lewis 2000). Conflicts have reduced since 1991, as households have diversified livelihoods to become less dependent on park resources. However, the Batwa still express concerns about cultural impacts of park management priorities, even following attempts to establish collaborative management programs to re-establish and renegotiate user rights of local people (RJ, IDEJ). These programs have generally failed leaving the Batwa as stakeholders but not decision-makers able to negotiate their fate (PJ). Although the Batwa do benefit from revenue sharing from tourism, the generally small size of these income streams contributes to negative assessments, with the perception that benefits of living near the forest do not outweigh costs and that tourism has not benefited them (DJ) (Martin et al. 2015). Laudati (2010) found that ecotourism actually created new forms of vulnerability of and control over the Batwa (IDEJ). From the viewpoint of the Batwa, the designation of the park over 20 years ago has left them unable to meet their most basic needs for nutritious food (SDG2) that underpins good health (SDG3). Instead of exclusion, convivial conservation and IDEJ could create an alternative approach that achieves SDG14 \& SDG15 without causing harm to local people.

\section{Poverty and inequality, beyond dollar signs (SDG1 and SDG10)}

SDG1 calls for "an end to poverty in all its manifestations by 2030. It also aims to ensure social protection for the poor and vulnerable, increase access to basic services, and support for people harmed by climate-related extreme events and other economic, social and environmental shocks and disasters."

However, while the SDG refers to poverty in all its manifestations, and acknowledges some multi-dimensional aspects of poverty, stressing services, and social protection, such as health (SDG3), education (SDG4), the SDG still centers on poverty primarily measured by income, with the target (3.1): "By 2030, eradicate extreme poverty for all people everywhere, currently measured as people living on less than $\$ 1.25$ a day". 
Increased income cannot compensate easily or at all for depletion of environmental resources or degradation of ecosystems (e.g., water availability, water quality, forest biomass, soil fertility, topsoil, inclement micro-climates, etc.). To take a simple example, if a mine opens in a community and income increases from $\$ 0.75$ to $\$ 1.25$ cents a day, but the water is now polluted by tailings and women need to walk several $\mathrm{km}$ to buy water for their household use, would it be just to consider that poverty had decreased?

Particularly absent is the acknowledgment that poverty often occurs when relations between healthy ecosystems and human well-being are damaged or broken due to depletion of resources or environmental degradation (SDG6, 14, 15). Healthy ecosystems are often the wealth of the poor and increased income cannot compensate in the face of environmental injustice.

Ecological economists (Common and Stagl 2005) have argued that GDP statistics obscure the real livelihood basis of many poor sectors of the world population, and fail to consider injustices caused by pollution, enclosure, and environmental degradation. The dependence of communities on things such as ecosystem services and goods outside the market (clean water, fertile soil, and locally adaptable seeds) has been termed the "GDP of the poor" (Sukdhev 2009), and it is estimated that this can make up between 50 and $90 \%$ of the total source of livelihoods among poor rural and forestdwelling households (TEEB 2010, Angelsen et al. 2014). As Scheidel (2013) argues, improvements in one poverty dimension cannot always compensate for the deterioration of other poverties.

While SDG1 focuses on alleviating poverty, it does not address any of the driving underlying structural factors that cause poverty. It does not address the issue of excessive wealth and overconsumption, increased inequality, and the relation with impoverishment of other's environments and labour exploitation. It does not touch on exploitation, dispossession, and disenfranchisement as the main leading causes of poverty. In this way, it does not encompass restorative approaches to EJ nor critical EJ.

Further, while it acknowledges threats and disasters brought on by "climate change, conflict and food insecurity" (1.5), it does not address how to reduce the structural underlying causes of food insecurity and climate change. This calls for specific policy measures widely advocated in environmental and agrarian justice approaches such as reducing and eliminating uneven agricultural subsidies, recognising peasant sovereignty over seeds (SDG2.5), stopping all landgrabbing (SDG2.3), regulating speculation on agricultural commodities and land reform.

Finally, while SDG1 calls for mobilisation of aid and development resources from rich to poor countries, it does not address world system dynamics such as trade rules, structural adjustment, debt burdens, etc. Poverty will not be meaningfully addressed by financial transfers, but calls for the dismantling of the international political and economic arrangements that systematically benefit the wealthy and disenfranchise the poor (Gonzalez 2014). This calls for a restructuring of the global economy and the underlying structural causes of food insecurity to address the root causes of the problem and not merely the immediate manifestations.

The focus on inequality under SDG10 has significant implications for the transition towards justice. However, the indicators for this target are heavily weighted towards financial and income-related measures of inequality (five out of seven indicators) which link directly to the income focus of SDG 1 discussed above. Strikingly, although SDG10 addresses inequality "between countries", the targets and related indicators do not address the accumulation of wealth by rich countries, nor the impacts of this wealth accumulation on financial systems or other well-being indicators within lower or middle-income countries.

As Paz Arauco et al. (2014, p. viii) point out: "tackling intersecting inequalities at the country level derives from a range of factors, which pertain more to social and political mobilisation for goals of social justice than they do to technocratic details of aid or policy formulation."

\section{Case study: oil in Ecuador}

Beyond the focus on international inequalities, it is also important to consider inequalities within countries. We look here at Ecuador as an example: Since 1972, Ecuador has been an oil exporter and oil became the backbone of the national economy, accounting for about half of exports. Comparative development studies point out structural hindrances facing extractive economies to reach equitable social distribution. Although national experiences are heterogeneous, predominance of extractive industries often leads to weak and unstable economic performance, minimal sectoral diversification, insufficient employment generation, and poor institutional development (Karl 1997, 1999, Berry 2008). Bebbington (2013) analyzes regional effects in extractive areas, finding frequent social conflict, uneven social development and the prevalence of poverty and exclusion.

Almost 5 decades later, it can be concluded that oil contributed little to equitable and sustainable development in Ecuador, in spite of some economic and social transformation. Economic growth remained evasive and unstable despite important social achievements during the oil boom (1972-1982) and between 2006 and 2014, the social, ethnic, and regional disparities that have historically affected the country remained pervasive, as $30 \%$ of the population lived below the poverty line, underemployment affected $40 \%$ of the labour force in 2017 and social inequality barely declined, as the Gini coefficient remained at 0.52 in 2015 (Vallejo et al 2015; Larrea 2018). 
Since oil extraction in Ecuador is located in a formerly undisturbed region in the Amazon basin, the environmental effects of oil activity have been severe, particularly regarding deforestation (SDG15), loss of biodiversity (SDG15), pollution (SDG6), and human health hazards (SDG3) (Herbert 2010; Amazon Defense Coalition 2012). Indigenous communities remain among the most heavily affected (IDEJ).

Evidence taken from national census data in 1990, 2001, and 2010 demonstrates that the oil extraction region in Ecuadorian Amazon barely benefited from oil extraction (Larrea 2018). Not only the Amazon region remains as the poorest region in the country, both in urban and rural areas, but also, within the Amazon region, social deprivations in education, health, housing, and employment are higher among parishes located in oil extractive areas, compared to those located outside the referred areas (Larrea 2018).

\section{Outright contradictions: sustainability and economic growth (SDG 8)}

SDG8 contradicts many of other goals. In its title "Decent work and Economic Growth", the word "growth" is not left aside (as in the slogan "sustainable development"). Quite plainly economic growth is introduced as a goal. Probably, in the international negotiations, this was a sine qua non. The objective is to "sustain per capita economic growth in accordance with national circumstances and, in particular, at least $7 \%$ gross domestic product growth per annum in the least developed countries". This is supposed to be possible, without environmental collapse, by "improving progressively, through 2030, global resource efficiency in consumption and production and endeavour to decouple economic growth from environmental degradation...".

Since at world level (taking into account currents of trade and displacement of environmental effects), there has not been such "decoupling" until now, the belief that there might be decoupling in the next 12 years is not plausible. As Tim Jackson says in his work Prosperity without Growth, "simplistic assumptions that capitalism's propensity for efficiency will allow us to stabilize the climate or protect against resource scarcity are nothing short of delusional... it is entirely fanciful to suppose that 'deep' emission and resource cuts can be achieved without confronting the structure of market economies" (Jackson 2009, p 86). Decoupling is not the answer.

SDG 8 is contradictory to many of the other goals, particularly SDG 13, on Climate Action. The increase in the Keeling curve, that shows atmospheric carbon dioxide since 1958, will continue with economic growth. Even remaining at the present level, and assuming zero economic growth in the world industrial economy, large amounts of fossil fuels will continue to be burned. As Hickel (2019) shows, SDG8 contradicts the sustainability objectives of the SDGs, because even growth at 3\% makes it impossible to reduce resource use and reduce carbon emissions enough to stay within the $2{ }^{\circ} \mathrm{C}$ warming limits.

As a first step, moving away from the push for economic growth would have been more conducive to achieving social and environmental justice. It would mean facing the "environmental liabilities" or "ecological debts" of the industrial economic system. Very relevant ones are those arising from climate change and from ecologically unequal trade (Hornborg and Martinez-Alier 2016). Notice that Paris COP agreement of 2015 explicitly excluded "environmental liability" for climate change-no recognition of those who claim that environmental liabilities (or, equivalently, ecological debts) should be faced.

The SDGs could have adopted instead the language of the encyclical "Laudato si" (taken from Latin American contributions) on this point of international environmental injustices: "Inequity affects not only individuals but entire countries; it compels us to consider an ethics of international relations. A true "ecological debt" exists, particularly between the global north and south, connected to commercial imbalances with effects on the environment, and the disproportionate use of natural resources by certain countries over long periods of time [SDG10]. The export of raw materials to satisfy markets in the industrialized north has caused harm locally, as for example in mercury pollution in gold mining or sulphur dioxide pollution in copper mining [SDG3, SDG6, SDG12].... The warming caused by huge consumption on the part of some rich countries has repercussions on the poorest areas of the world, especially Africa, where a rise in temperature, together with drought, has proved devastating for farming [SDG2, SDG13]". There is also the damage caused by the export of solid waste and toxic liquids to developing countries, and by the pollution produced by companies which operate in less-developed countries in ways they could never do at home, in the countries in which they raise their capital [SDG3, SDG6, SDG12, and SDG15]: "We note that often the businesses which operate this way are multinationals. They do here what they would never do in developed countries or the so-called first world. Generally, after ceasing their activity and withdrawing, they leave behind great human and environmental liabilities such as unemployment [SDG1, SDG8], abandoned towns [SDG1, SDG11], the depletion of natural reserves, deforestation, the impoverishment of agriculture and local stock breeding, open pits, riven hills, polluted rivers and a handful of social works which are no longer sustainable [SDG2, SDG6, SDG14, SDG15]" (Pope Francis 2015, paragraph 51).

Instead of aiming for economic growth, the SDGs could instead build upon advances in the field of 'sustainable degrowth' which acknowledges the limits of the earth's systems to cope with continued growth, the inability of 
technological efficiency to meet growing demands, and the need to 'down-shift' sustainably to reduce society's throughput (or emissions and related use of resources) (Kallis 2011). Although EJ has emerged from grassroots movements and degrowth has remained largely theoretical to date, they "share a common quest for profound socioecological transformations towards justice and sustainability, and that an alliance among these research and activist communities is essential" (Akbulut et al. 2019, p 7). As Singh (2019) asserts, they both "aspire for other ways of being and belonging to the world and open possibilities for postcapitalist futures" ( $p$ 1). Although the frameworks for "sustainable development' often have not aligned with those of 'sustainable degrowth', it could be argued that they should, and indeed must be reconciled.

\section{Conclusions}

The interactions among the SDGs are complex, leading to a wide range of potential implications for environmental justice. While environmental justice is not addressed explicitly in the text of the goals, many of the goals and targets have implications for EJ, both positive and negative.

The synergies, gaps, and contradictions highlighted in the examples above emphasize the need to acknowledge power relations and to move beyond a focus on economic growth (SDG8) and income-based indicators of poverty (SDG1) that mask the complex multi-dimensional nature of poverty and the conditions needed to ensure human well-being. The SDGs need an approach that puts in debate the trade-offs and power challenges of moving toward a more sustainable and just society: a transition towards goals that are focused on values, solidarity, and diversity.

We argue for the incorporation of EJ for humans and non-humans as a prerequisite to sustainability. Equally, EJ frameworks need to move beyond a focus on the four principles of mainstream EJ (distribution, procedure, recognition, and capabilities) towards a more intersectional decolonial approach to environmental justice. To bring about a transition to just sustainability, governments and other stakeholders must address the contradictions inherent in the focus of the SDGs on economic growth, which has been shown to lead to extensive environmental degradation, loss of nonhuman species, and damage to the health and well-being of marginalised peoples. More must be done to address the 'elephant in the room' also known as economic growth, to moved beyond promises of decoupling between growth and environmental destruction towards sustainable degrowth that respects the intersectionality of the injustices facing marginalised groups. SDGs should recognise power dynamics, complex interactions among injustices, and create mechanisms to address the different 'senses of justice' and desires and epistemologies of theorists, activists, and other stakeholder from the Global South who are often the ones most negatively impacted by the injustices linked to development.

Acknowledgements The authors would like to acknowledge funding from the Sussex Sustainability Research Programme, University of Sussex; and ERC Adv. Grant EnvJustice, 2016-21. GA 695446. We would also like to thank the anonymous reviewers and Aoife Bennett for helpful feedback on earlier drafts of the manuscript.

Open Access This article is licensed under a Creative Commons Attribution 4.0 International License, which permits use, sharing, adaptation, distribution and reproduction in any medium or format, as long as you give appropriate credit to the original author(s) and the source, provide a link to the Creative Commons licence, and indicate if changes were made. The images or other third party material in this article are included in the article's Creative Commons licence, unless indicated otherwise in a credit line to the material. If material is not included in the article's Creative Commons licence and your intended use is not permitted by statutory regulation or exceeds the permitted use, you will need to obtain permission directly from the copyright holder. To view a copy of this licence, visit http://creativecommons.org/licenses/by/4.0/.

\section{References}

Adeola FO (2000) Cross-national environmental injustice and human rights issues: a review of evidence in the developing world. Am Behav Scient 43(4):686-706

Agarwal B (2001) Participatory exclusions, community forestry, and gender: an analysis for South Asia and a conceptual framework. World Dev 29:1623-1648

Agyeman J (2008) Toward a 'just' sustainability? Continuum 22(6):751-756. https://doi.org/10.1080/10304310802452487

Agyeman J, Evans B (2004) 'Just sustainability': the emerging discourse of environmental justice in Britain? Geograph J 170(2):155-164

Agyeman J, Bullard RD, Evans B (2002) Exploring the nexus: bringing together sustainability, environmental justice and equity. Space Polity 6(1):77-90

Akbulut B, Demaria F, Gerber JF, Martínez-Alier J (2019) Who promotes sustainability? Five theses on the relationships between the degrowth and the environmental justice movements. Ecol Econom 165:106418

Akizu O, Urkidi L, Bueno G, Lago R, Barcena I, Mantxo M, Basurko I, Lopez-Guede J (2017) Tracing the emerging energy transitions in the Global North and the Global South. Intl J Hydrogen Energy 42(28):18045-18063. https://doi.org/10.1016/j.ijhyd ene.2017.04.297

Aldred J (2012) The ethics of emissions trading. New Polit Econ 17(3):339-360. https://doi.org/10.1080/13563467.2011.578735

Álvarez L, Coolsaet B (2018) Decolonizing environmental justice studies: a Latin american perspective. Capitalism Nature Socialism, pp $1-20$

Amazon Defense Coalition (2012) Summary of overwhelming evidence against chevron in ecuador Trial. https://chevrontoxico. com/assets/docs/2012-01-evidence-summary.pdf

Angelsen A, Jagger P, Babigumira R, Belcher B, Hogarth NJ, Bauch S, Börner J, Smith-Hall C, Wunder S (2014) Environmental income and rural livelihoods: a global-comparative analysis. World Dev 64:S12-S28

Avila S (2018) Environmental justice and the expanding geography of wind power conflicts. Sustain Sci 13(3):599-616 
Barreto JM (ed) (2014) Human rights from a third world perspective: critique, history and international law. Cambridge Scholars Publishing, Cambridge

Bartlett A (1994) Reflections on sustainability, population growth and the environment. Popul Environ 16:5-35

Baxter B (2004) A theory of ecological justice. Routledge, London

Bebbington A (2013) Industrias extractivas: conflicto social y dinámicas institucionales en la Región Andina. IEP, Lima

Bell D, Carrick C (2017) Procedural environmental justice. The Routledge Handbook of Environmental Justice

Berry A (2008) Growth, employment and distribution impacts of minerals dependency: four case studies. S Afr J Econ 76(2):148-174

Bluwstein J, Lund JF (2018) Territoriality by conservation in the Selous-Niassa Corridor in Tanzania. World Dev 101:453-465

Bullard R (1990) Dumping in dixie: race, class, and environmental quality. Westview Press, Boulder

Bullard R (1993) Confronting environmental racism: voices from the grassroots. South End Press, Boston

Büscher B, Fletcher R (2019) Towards convivial conservation. Conserv Soc 17(3):283-296

Büscher B, Ramutsindela M (2015) Green violence: Rhino poaching and the war to save Southern Africa's peace parks. Afr Affairs 115(458):1-22

Butt N, Lambrick F, Menton M, Renwick A (2019) The supply chain of violence. Nat Sustain 2(8):742-747

Chomba S, Kariuki J, Lund JF, Sinclair F (2016) Roots of inequity: how the implementation of REDD+ reinforces past injustices. Land Use Pol 50:202-213. https://doi.org/10.1016/j.landusepol .2015.09.021

Colchester M (2003) Indigenous peoples and protected areas: rights, principles and practice. Nomad People 7:33-51. https://doi. org $/ 10.3167 / 082279403782088840$

Cole LW, Foster SR (2001) From the ground up: environmental racism and the rise of the environmental justice movement, vol 34. New York University Press, London

Common M, Stagl S (2005) Ecological economics: an introduction. Cambridge University Press, Cambridge

Crenshaw K (1989) Demarginalizing the intersection of race and sex: a black feminist critique of antidiscrimination doctrine, feminist theory and antiracist politics. u. Chi. Legal f. p 139

Crenshaw K (1991) Mapping the margins: intersectionality, identity politics, and violence against women of color. Stanford Law Rev 43:1241-1299

Crist E (2012) Abundant earth and population. In: Cafaro P, Crist E (eds) Life on the brink: environmentalists confront overpopulation. University of Georgia Press, Athens, pp 141-153

Cruz FSM (2017) Quando a terra sair: os índios Tuxá de Rodelas e a barragem de Itaparica: memórias do desterro, memórias da resistência. Masters dissertation. University of Brasília, Brazil

Duffy R (2016) War, by conservation. Geoforum 69:238-248

Dunlap A (2018) The 'solution' is now the 'problem': wind energy, colonisation and the 'genocide-ecocide nexus' in the Isthmus of Tehuantepec. Oaxaca Int J Human Rights 22(4):550-573

Dunlap A (2019) Renewing destruction: wind energy development, conflict and resistance in a Latin American context. Rowman \& Littlefield International.

Easterly W (2015) The trouble with the sustainable development goals. Curr Hist 114(775):322

EJAtlas (2017) Corporate wind farms in ixtepec vs community's inititiative, Oaxaca, Mexico. https://ejatlas.org/conflict/communalmembers-of-ixtepec-contending-to-develop-a-wind-farm-coope rative. Accessed 5 Aug 2019

EJAtlas (2019) New Bwindi Impenetrable National Park, Uganda. https ://ejatlas.org/conflict/new-bwindi-impenetrable-national-parkuganda. Accessed 16 Jan 2020
Farmer P (2004) An anthropology of structural violence. Curr Anthropol 45(3):305-325

Forsyth T (2014) Climate justice is not just ice. Geoforum 54:230-232. https://doi.org/10.1016/j.geoforum.2012.12.008

Francis P (2015) Laudato si: on care for our common home. Our Sunday Visitor

Fraser N (1995) Recognition or redistribution? A critical reading of iris young's justice and the politics of difference. J Pol Phil $3: 166-180$

Fraser N (1998) Social justice in the age of identity politics: redistribution, recognition and participation. Tanner Lect Human Values 19:2-67

Front Line Defenders (2019) Front line defenders global analysis 2018. Front Line Defenders, Dublin, Ireland. https://www.front linedefenders.org/sites/default/files/global_analysis_2018.pdf. Accessed 16 Jan 2020

Global Witness (2018) Enemies of the state? How governments and business silence land and environmental defenders. https://www. globalwitness.org/fr/campaigns/environmental-activists/enemi es-state/. Accessed 16 Jan 2020

Godden L, Tehan M (2016) REDD+: climate justice and indigenous and local community rights in an era of climate disruption. J Energy Nat Res Law 34(1):95-108. https://doi. org/10.1080/02646811.2016.1121620

Gonzalez CG (2014) World poverty and food insecurity. Penn St JL Intl Aff 3:56

Heffron RJ, McCauley D (2017) The concept of energy justice across the disciplines. Energy Pol 105:658-667. https://doi. org/10.1016/j.enpol.2017.03.018

Herbert B (2010) Disaster in the amazon. NY Times 4

Hernández D (2015) Sacrifice along the energy continuum: a call for energy justice. Environ Justice 8(4):151-156. https://doi. org/10.1089/env.2015.0015

Hickel J (2019) The contradiction of the sustainable development goals: growth versus ecology on a finite planet. Sust Dev 27(5):873-884

Hickel J (2020) The sustainable development index: measuring the ecological efficiency of human development in the anthropocene. Ecol Econ 167:106331

Higgins P (2012) Eradicating ecocide. Shepheard Walwyn, London

Holifield R, Chakraborty J, Walker W (2018) The Routledge handbook of environmental justice. Routledge, New York

Honneth A (2001) Recognition or redistribution? Changing perspectives on the moral order of society. Theory Cult Soc 18(2-3):43-55

Hornborg A, Martinez-Alier J (2016) Ecologically unequal exchange and ecological debt. J Polit Ecol 23(1):328-333

Jackson T (2009) Prosperity without growth: economics for a finite planet. Routledge, New York

Jenkins K (2018) Setting energy justice apart from the crowd: lessons from environmental and climate justice. Energy Res Soc Sci 39:117-121. https://doi.org/10.1016/j.erss.2017.11.015

Jenkins K, McCauley D, Heffron R, Stephan H, Rehner R (2016) Energy justice: a conceptual review. Energy Res Soc Sci 11:174182. https://doi.org/10.1016/j.erss.2015.10.004

Kallis G (2011) defence of degrowth. Ecol Econ 70(5):873-880

Karl TL (1997) The paradox of plenty: oil booms and petro-states, vol 26. Univ of California Press, California

Karl T (1999) The perils of the Petro-state: reflections on the paradox of plenty. J Int Affairs 53(1):31-48

Knox JH (2009) Climate change and human rights law. Va J Intl L $50: 163$

Knox JH (2015) Human rights, environmental protection, and the sustainable development goals. Wash Intl L J 24:517

Knox JH, Pejan R (eds) (2018) The human right to a healthy environment. Cambridge University Press, Cambridge 
Kopnina H (2016) The victims of unsustainability: a challenge to sustainable development goals. Int J Sustain Dev World Ecol 23(2):113-121

Kopnina H, Washington H (2020) Conservation and justice in the anthropocene: definitions and debates. In: Kopnina H, Washington $\mathrm{H}$ (eds) Conservation: integrating ecological and social justice. Springer, Cham, pp 3-15

Landrigan PJ, Fuller R, Acosta NJ, Adeyi O, Arnold R, Baldé AB, Bertollini R, Bose-O'Reilly S, Boufford JI, Breysse PN, Chiles $\mathrm{T}$ (2018) The Lancet Commission on pollution and health. Lancet 391(10119):462-512

Larrea C (2018) Está agotado el período perolero en Ecuador? Quito: UASB-La Tierra-Amazon, Quito. https://www.amazo n.com/\%C2\%BFEst\%C3\%A1-agotado-periodo-petroleroEcuador-ebook/dp/B07GWYLDXH

Laudati A (2010) Ecotourism: the modern predator? Implications of gorilla tourism on local livelihoods in Bwindi Impenetrable National Park. Uganda Environ Plan D Soc Space 28(4):726-743

Lele S (2017) Sustainable development goal 6: watering down justice concerns. Wiley Interdiscip Rev Water 4(4):e1224

Lewis J (2000) The Batwa Pygmies of the Great Lakes Region, a Report of Minority Rights Group. https://minorityrights.org/ wp-content/uploads/old-site-downloads/download-150-Batwa -Pygmies-of-the-Great-Lakes-Region.pdf. Accessed 16 Jan 2020

Lohmann L (2004) Carbon trading - a critical conversation on climate change, privatisation and power. Dev Dialogue 48. Dag Hammarskjöld Foundation, Uppsala

Malin SA, Ryder SS (2018) Developing deeply intersectional environmental justice scholarship. Environ Sociol 4(1):1-7

Marijnen E, Verweijen J (2016) Selling green militarization: the discursive (re) production of militarized conservation in the Virunga National Park, Democratic Republic of the Congo. Geoforum 75:274-285

Martin A, Akol A, Gross-Camp N (2015) Towards an explicit justice framing of the social impacts of conservation. Conserv Soc 13(2):166-178

Martinez-Alier J, Temper L, Del Bene D, Scheidel A (2016) Is there a global environmental justice movement? J Peasant Stud 43(3):731-755

McCarthy J (2015) A socioecological fix to capitalist crisis and climate change? The possibilities and limits of renewable energy. Environ Plan A Econ Space 47(12):2485-2502. https://doi. org/10.1177/0308518x15602491

McDermott CL, Acheampong E, Arora-Jonsson S, Asare R, de Jong W, Hirons M, Khatun K, Menton M, Nunan F, Poudyal M, Setyowati A (2019) A focus on SDG 16: peace, justice and strong institutions. In: Colfer $\mathrm{C}$ et al (eds) The sustainable development goals: their impacts on forests and people. IUFRO.

Mignolo WD (2007) Delinking: the rhetoric of modernity, the logic of coloniality and the grammar of de-coloniality. Cult Stud 21(2-3):449-514

Mugagga F, Nabaasa B (2016) The centrality of water resources to the realization of Sustainable Development Goals (SDG). A review of potentials and constraints on the African continent. Int Soil Water Conserv Res 4(3):215-223

Mutua M (2013) Human rights: a political and cultural critique. University of Pennsylvania Press, Philadelphia

Myers N, Mittermeier RA, Mittermeier CG, da Fonseca GAB, Kent J (2000) Biodiversity hotspots for conservation priorities. Nature 403:853-858. https://doi.org/10.1038/35002501.10706275

Nilsson M, Griggs D, Visbeck M (2016) Policy: map the interactions between Sustainable Development Goals. Nat News 534(7607):320
Nixon R (2011) Slow violence and the environmentalism of the poor. Harvard University Press, Harvard

Nussbaum MC (2011) Creating capabilities. Harvard University Press, Cambridge

O’Manique C, Fourie P (2016) Affirming our world: gender justice, social reproduction, and the sustainable development goals. Development 59(1-2):121-126

Omisore AG (2018) Attaining sustainable development goals in subSaharan Africa; the need to address environmental challenges. Environ Dev 25:138-145

O’Neill DW, Fanning AL, Lamb WF, Steinberger JK (2018) A good life for all within planetary boundaries. Nat Sustain 1(2):88 95. https://doi.org/10.1038/s41893-018-0021-4

Paz Arauco V, Gazdar H, Hevia-Pacheco P, Kabeer N, Lenhardt A, Masood SQ, Naqvi H, Nayak N, Norton A, Sabharwal NS, Scalise E (2014) Strengthening social justice to address intersecting inequalities post-2015. Overseas Development Institute (ODI) Policy Briefing.

Pellow DN (2016) Toward a critical environmental justice studies. Du Bois Rev Soc Sci Res Race 13:221-236. https://doi.org/10.1017/ S1742058X1600014X

Pellow DN (2018) What is critical environmental justice?. Polity Press, Cambridge

Pradhan P, Costa L, Rybski D, Lucht W, Kropp JP (2017) A systematic study of sustainable development goal (SDG) interactions. Earth's Future 5(11):1169-1179

Pulido L (1996) Environmentalism and social justice: two chicano struggles in the Southwest. University of Arizona Press, Tucson

Pulido L, De Lara J (2018) Reimagining 'justice' in environmental justice: Radical ecologies, decolonial thought, and the Black Radical Tradition. Environ Plan E Nat Space 1(1-2):76-98

Quijano A (2007) Coloniality and modernity/rationality. Cult Stud 21(2-3):168-178

Robeyns I (2005) The capability approach: a theoretical survey. J Human Dev 6(1):93-117

Savaresi A (2016) The Paris agreement: a new beginning? J Energy Nat Resour Law 34(1):16-26. https://doi.org/10.1080/02646 811.2016.1133983

Scheidel A (2013) Flows, funds and the complexity of deprivation: using concepts from ecological economics for the study of poverty. Ecol Econ 86:28-36

Scheidel A, Temper L, Demaria F, Martínez-Alier J (2018) Ecological distribution conflicts as forces for sustainability: an overview and conceptual framework. Sustain Sci 13(3):585-598

Schlosberg D (2007) Defining environmental justice: theories, movements, and nature. Oxford University Press, New York

Schlosberg D (2013) Theorising environmental justice: the expanding sphere of a discourse. Environ Politics 22(1):37-55

Schlosberg D, Carruthers D (2010) Indigenous struggles, environmental justice, and community capabilities. Glob Environ Polit 10(4):12-35

Schlosberg D, Collins LB (2014) From environmental to climate justice: climate change and the discourse of environmental justice. Wiley Interdiscip Rev Clim Change 5(3):359-374. https://doi. org/10.1002/wcc. 275

Sen A (1999) Development as freedom. In: Roberts JT, Hite AB, Chorev N (eds) (2014) The globalization and development reader: perspectives on development and global change. Wiley, New York, p 525

Sikor T (ed) (2013) The justices and injustices of ecosystem services. Routledge, Abingdon

Sikor T, Newell P (2014) Globalizing environmental justice? Geoforum 54:151-157. https://doi.org/10.1016/j.geoforum.2014.04.009

Singh NM (2019) Environmental justice, degrowth and post-capitalist futures. Ecol Econ 163:138-142 
Sovacool BK, Dworkin MH (2015) Energy justice: Conceptual insights and practical applications. Appl Energy 142:435-444. https://doi. org/10.1016/j.apenergy.2015.01.002

Spash CL (2016) This changes nothing: the Paris agreement to ignore reality. Globalizations 13(6):928-933. https://doi. org/10.1080/14747731.2016.1161119

Suich H, Howe C, Mace G (2015) Ecosystem services and poverty alleviation: a review of the empirical links. Ecosyst Serv 12:137147. https://doi.org/10.1016/j.ecoser.2015.02.005

Sukhdev P (2009) Costing the earth. Nature 462(7271):277

Svarstad H, Benjaminsen TA (2020) Reading radical environmental justice through a political ecology lens. Geoforum 108:1-11

TEEB (2010) The economics of ecosystems and biodiversity: mainstreaming the economics of nature: a synthesis of the approach. Conclusions and Recommendations of TEEB.

Temper L (2018) Globalizing environmental justice: radical and transformative movements past and present. In: Holifield R, Chakraborty J, Walker G (eds) The Routledge handbook of environmental justice. Routledge, London, pp 490-503

Temper L (2019) Blocking pipelines, unsettling environmental justice: from rights of nature to responsibility to territory. Local Environment 24(2):94-112

Temper L, Del Bene D, Martinez-Alier J (2015) Mapping the frontiers and front lines of global environmental justice: the EJAtlas. J Polit Ecol 22(1):255-278

United Nations (2015) Transforming our world: the 2030 Agenda for Sustainable Development. https://sustainabledevelopment.un. org/post2015/transformingourworld/publication. Accessed 16 Jan 2020
United Nations (2017) Global indicator framework for the Sustainable Development Goals and targets of the 2030 Agenda for Sustainable Development. UN Resolution A/RES/71/313

Vallejo MC, Burbano R, Falconí F, Larrea C (2015) Leaving oil underground in Ecuador: the Yasuní-ITT initiative from a multi-criteria perspective. Ecol Econ 109:175-185. https://doi. org/10.1016/j.ecolecon.2014.11.013

Vermeylen S (2019) Environmental justice and epistemic violence. Local Environ 24:89-93

Vivero Pol JL, Schuftan C (2016) No right to food and nutrition in the SDGs: mistake or success? BMJ Glob Health 1(1):e000040

Walker G (2009) Globalizing environmental justice. Glob Soc Pol 9(3):355-382

Walzer M (1983) Spheres of justice. Blackwell, Oxford

Warren T, Baker KJM (2019) WWF funds guards who have tortured and killed people. Buzzfeed news investigation. https://www. buzzfeednews.com/article/tomwarren/wwf-world-wide-fundnature-parks-torture-death Accessed 5 Aug 2019

Washington H (2015) Demystifying sustainability: towards real solutions. Routledge, London

Woods K (2006) What does the language of human rights bring to campaigns for environmental justice? Environ Polit 15(4):572-591

Young I (1990) Justice and the politics of difference. Princeton University Press, Princeton

Publisher's Note Springer Nature remains neutral with regard to jurisdictional claims in published maps and institutional affiliations. 